THE CULTURAL ORIGINS

OF HUMAN COGNITION 



\section{THE CULTURAL ORIGINS OF HUMAN COGNITION}

Michael Tomasello

HARVARD UNIVERSITY PRESS

Cambridge, Massachusetts

London, England 1999 
Copyright $($ ) 1999 by Michael Tomasello

All rights reserved

Printed in the United States of America

First Harvard University Press Paperback edition, 2000

Library of Congress Cataloging-in-Publication Data

Tomasello, Michael.

The cultural origins of human cognition / Michael Tomasello.

p. $\quad \mathrm{cm}$.

Includes bibliographical references and index.

ISBN 0-674-00070-6 (cloth)

ISBN 0-674-00582-1 (paper)

1. Cognition and culture. 2. Cognition in children. I. Title.

BF311.T647 1999

153-dc21 99-35902 